\title{
Language Educational Observations in a Multicultural Kindergarten
}

\author{
Kitzinger Arianna \\ Nyugat-magyarországi Egyetem, Benedek Elek Pedagógiai Kar, Sopron
}

\begin{abstract}
The study gives an insight into language educational observations followed in a Hungarian multilingual-multicultural kindergarten. It briefly describes the special setting in Fáy András Kindergarten, Pápa, where 23 foreign families' children were received in September 2008. The aim of the article is to give reasons why observation as a research method was chosen in spite of its relative difficulties under pre-school circumstances: how its drawbacks could be overcome and how its benefits could be exploited. Besides, it gives an account of the applied research tools and technology which may prove to be indispensable during educational observations. The report gives a closer look at the kindergarten activities which help children and kindergarten teachers to create a linguistic, educational and social community, and then discusses the relevant language educational issues. Conclusions along discussion are also made to reveal the prominent interrelations and interdependence in this complex educational setting.
\end{abstract}

Key-words: language pedagogy, multilingual and multicultural, kindergarten, observation methods, linguistic and cultural diversity

\section{The Background}

Since September 2008 the children of foreign families working at the air base of Pápa have been going to the local Fáy András Kindergarten, which was appointed to be their host institution by the self government of the town. Families came from NATO members and two Partnership for Peace nations in the frame of the Strategic Airlift Capability programme called SAC/C-17 (Strategic, 2013). Families are usually made up of young parents and their children who go either to school or to the kindergarten. Their delegation lasts approximately for 1,5-4 years. This unique multilingual-multicultural kindergarten hosts 23 foreign families' children from 6 different countries and from the host country, namely from Sweden, Bulgaria, Poland, Norway the Netherlands, the United States, and Hungary, naturally. Apart from Hungarian, mother tongues of the children are Swedish, Bulgarian, Polish, Norwegian, Dutch and, in the case of the American families, English, Filipino and Spanish. The setting is exceptional as NATO bases establish their own international schools elsewhere in the world. The town of Pápa, Hungary is, however, the first place where foreign children are trying to adapt to the local community from linguistic, social, educational and cultural points of view.

Multilingualism has been widely examined from the aspect of linguistics just like early childhood education from the side of pedagogy. There are researchers also in Hungary who deal with bilingualism (e.g. Bartha, 1999; Navracsics, 2007, 2008, 2010), childhood language acquisition (e.g. Kovács, 2002, 2008, 2009a, b), or multiculturalism (e.g. Cs. Czachesz, 1998; Torgyik, 2005; Varga, 2006), yet the social situation and the educational setting is so novel in Hungary that a gap in the discussion can be noticed.

\section{Observation as a Research Method}

As an organic part of triangulation I chose observation as one of my research methods. It is an indispensable method in language educational research, because the researcher 
can find him-/herself in lifelike situations where the previous hypotheses can be accepted or rejected in real life settings. Other methods (e.g. interviews or document analysis) cannot be replaced but can be effectively completed by observation. The findings are tangible and the results are supported by authentic experience on the spot.

Observation applied by pedagogues or linguists and ethnographic field work, which was borrowed from anthropologists, have a lot in common (Byram \& Zarate, 1994; Byram, 1997; Roberts et al., 2001). Observers of both types of research should be supplied with information about the setting prior to the actual visit of the scene. They have to know what they want to focus on and what their reasons are. They should prepare with a research design and find the appropriate methodology for the sake of successful research but they must not underestimate the appearance of unexpected situations and their proper treatment as they might be beneficial, too. They must not forget about technical equipment either.

As far as methodology is concerned, we might choose from different types of research strategies. Among them participant observation might offer the most benefit as the most firsthand results can be gained from it and the "Having Been There" (Eisenhart, 2006, 573) experience can be displayed. Time period also has to be determined. The more time a researcher can spend in the given setting the more he/ she is involved and the more he/ she can exploit from observation. As far as the present exploration is concerned I tailored the needs to my possibilities and managed to create a combined strategy which is shown in a) the time spent on the spot, b) my status in the kindergarten and c) the equipment I used.

As a practising teacher I could not spend long continuous periods in the kindergarten. In this sense I did not become an anthropologist who can observe the setting and the situations for a relatively long and an uninterrupted time period. What I kept in view and managed to carry out is a gradual approach. Observation is a delicate stage of this research as not only adults (parents and kindergarten teachers) should accept and get adjusted to my presence in the kindergarten but children as well. As Fáy András Kindergarten is not a kindergarten affiliated to a teacher training institute, the appearance of an outsider is not part of their daily routine.

Group observation took place three times within six weeks in the spring of 2011. According to my gradual strategy by that time I had been in contact with the kindergarten teachers for three years, I had regularly visited the kindergarten with my colleagues and students, and I had done all the interviews with the parents. Whenever I visited the kindergarten (e.g. during the times of parental interviews) I endeavoured to get acquainted with the children and to make friends with them; I never missed greeting them and talking to them. Due to this regular contact when the time of observation arrived, we were not strangers; and the "observer's paradox" (Labov, 1972. 209.) could be minimised as much as possible.

In this way I confirmed my status in the kindergarten with children, kindergarten teachers, nurses and parents. During group observations I played neither the role of a participant observer nor that of an outsider. I tried to maintain the proper balance between the two extremes: as far as communication and interactions with children are concerned I was considered to be a participant observer while I avoided intervening in pedagogical or linguistic situations on purpose as an outsider. On the basis of time period, regularity and the informal style with the children this type of researcher attitude might be characteristic of a so-called semi-participant observer.

My participation partially depended on the equipment I used as well, namely a self-designed observation scheme. It was designed in a grid format (Table 1) so that recordings can be seen as linear and parallel order at the same time. In this way successive actions can be seen vertically while different aspects are described horizontally 
according to the actual time of events. Grids are easy to handle as they are perspicuous, thus transparency is guaranteed for further analysis. In spite of the advantages of tailor-made items it is advisable for the researcher to memorise the contents of the items beforehand for the sake of smooth recoding.

\begin{tabular}{|c|c|c|c|c|c|}
\hline $\begin{array}{c}1 . \\
\text { PROCEDURES }\end{array}$ & \multicolumn{2}{|c|}{$\begin{array}{cc}2 . \\
\text { LINGUISTIC FEATURES } \\
\text { children } & \begin{array}{c}\text { kindergarten } \\
\text { teacher }\end{array}\end{array}$} & $\begin{array}{c}3 . \\
\text { PEDAGOGICAL } \\
\text { TOOLS and } \\
\text { METHODS }\end{array}$ & $\begin{array}{c}4 . \\
\text { CULTURAL } \\
\text { PHENOMENA }\end{array}$ & $\begin{array}{c}5 . \\
\text { COMMENTS }\end{array}$ \\
\hline $\begin{array}{l}\text { - daily schedule } \\
\text { - activities } \\
\text { (L developing, } \\
\text { other; } \\
\text { spontaneous - } \\
\text { curricular) } \\
\text { - play (types, } \\
\text { children's } \\
\text { participation - } \\
\text { how many with } \\
\text { the same L1) } \\
\text { - parents' } \\
\text { role (at the } \\
\text { beginning/ end } \\
\text { of the day) }\end{array}$ & $\begin{array}{l}\text { - proportion of } \\
\text { Ls (according to } \\
\text { different Ls and } \\
\text { time) } \\
\text { - active and } \\
\text { passive L use } \\
\text {-meta- } \\
\text { communication, } \\
\text { gestures (as L } \\
\text { substitutes or } \\
\text { reinforcement) } \\
\text { - L use: code- } \\
\text { switching and } \\
\text { code-mixing } \\
\text { - children's } \\
\text { reactions: } \\
1 . \text { migrants in } \\
\text { HU } \\
2 . \text { HU children } \\
\text { in } \\
\quad \text { L2 } \\
\text { - mistakes } \\
\text { (lexical, syntactic) } \\
\text { - correction }\end{array}$ & $\begin{array}{l}\text { - proportion } \\
\text { of Ls } \\
\text { (according to } \\
\text { diff. Ls and time) } \\
\text { - individual } \\
\text { differentiation } \\
\text { - speech panels } \\
\text {-meta- } \\
\text { communication, } \\
\text { gestures (as L } \\
\text { substitutes or } \\
\text { reinforcement) } \\
\text { - feedback (+/ -) } \\
\text { - L use: code- } \\
\text { switching and } \\
\text { code-mixing } \\
\text { - k-g teacher's } \\
\text { role (mediator/ } \\
\text { leader) } \\
\text { - mistakes } \\
\text { (lexical, } \\
\text { syntactic) } \\
\text { - correction }\end{array}$ & $\begin{array}{l}\text {-authentic } \\
\text { materials } \\
\text { (books, } \\
\text { cassettes, etc.) } \\
\text {-illustrative } \\
\text { materials (flash } \\
\text { cards, pictures, } \\
\text { etc.) } \\
\text { - conflicts \& } \\
\text { solution }\end{array}$ & $\begin{array}{l}\text { - child-to-child } \\
\text { interaction } \\
\text { (according to } \\
\text { nationalities) } \\
\text { - cultural } \\
\text { differences } \\
\text { (e.g. during } \\
\text { eating, sleeping) }\end{array}$ & \\
\hline
\end{tabular}

Table 1: The content part of the working copy of the final observation chart (Abbreviations: $\mathrm{HU}=$ Hungarian, $\mathrm{k}-\mathrm{g}=$ kindergarten, $\mathrm{L}=$ language, $\mathrm{L} 1$ = first language, $\mathrm{L} 2=$ second language)

Besides the observation chart I had some technical support such as a digital camera and a DVD-recorder whose content was later burnt on a DVD disc. I needed the equipment for different stages of observation. I very soon realised that due to the different characteristic features of the educational institutions, (school) classroom observation and (kindergarten) group observation do differ especially as far as 1 . children's and 2. (kindergarten) teachers' behaviour and 3. school settings are concerned. I summarise the major difference in the chart below (Table 2):

\begin{tabular}{|c|c|c|c|}
\hline & Aspects & $\begin{array}{l}\text { Classroom observation } \\
\text { at school }\end{array}$ & $\begin{array}{l}\text { Group observation } \\
\text { in the kindergarten }\end{array}$ \\
\hline \multirow[t]{6}{*}{1.} & \multicolumn{3}{|l|}{ children's } \\
\hline & mobility & limited (e.g. classroom arrangement) & free (e.g. mobile furniture) \\
\hline & interaction & directed (e.g. repetition) & free (e.g. during activities) \\
\hline & activities & regulated (e.g. lessons) & free (e.g. children can choose) \\
\hline & communication & $\begin{array}{l}\text { limited \& in certain periods (e.g. } \\
\text { when activities allow it) }\end{array}$ & $\begin{array}{l}\text { free \& spontaneous } \\
\text { (e.g. children can talk to anybody) }\end{array}$ \\
\hline & spontaneity & minimal & not limited \\
\hline \multirow[t]{2}{*}{2.} & \multicolumn{3}{|l|}{ teachers' } \\
\hline & role & mostly directive & mostly initiative or mediating \\
\hline 3. & setting & classrooms for subjects & group rooms for any activity \\
\hline
\end{tabular}

Table 2: The difference between school and kindergarten observation 
Although modern pedagogical methods make school, especially the lower grades less directed by the teacher than depicted in the chart above, kindergartens still provide a more stress free atmosphere for children which is beneficial in language development among other activities. Here I do not wish to provide any justification for different pedagogical methods just examine the question from the suitability of observation techniques. On the whole, I found that some techniques which could be reasonable and practical under school circumstances would fail in the kindergarten. For instance, I could not base the research on DVD-recording as in a kindergarten a great number of children groups are formed and the noise level is so high that making valid recordings during free playing activity time is impossible. I truly agree with Wragg who draws researchers' attention to the fact that "Classrooms are exceptionally busy places, so observers need to be on their toes" $(1999,2)$. However, when the kindergarten teacher makes initiatives to gather children for a common activity (it might be a so-called "talking circle", listening to a tale, singing together or the everyday physical exercises), recordings might be useful.

I must also mention here that children in the kindergarten, according to their age characteristics sometimes do not produce long and coherent dialogues with their peers or the kindergarten teachers, thus it is more difficult to record and follow their verbal communication. On the other hand, speeches to themselves can be noticed while playing, which causes further difficulties in the observation. Therefore very often the researcher faces difficulties and cannot put the mosaics and fragments of conversations into a wider context. Obviously, it is a drawback that serves as a limit to the research.

According to the previous conceptions I decided to employ a mixed method research where observation is adjusted to the actual activities. Therefore I used the designed observation chart in the group room during free play activities, the camera in the group room, the corridors and the yard to take photos of the setting and the DVD-recorder to make records of kindergarten teacher initiated group activities. It might be important to note that even these activities are not obligatory for the children. If they do not want to take part, they can play on their own or with the group's pedagogical assistant.

I made observations in 3 groups with 61 children, 4 kindergarten teachers and 3 pedagogical assistants. Free playing activities varied from constructive plays through board games to role-plays; among the "initials", which are activities triggered by the kindergarten teacher, I observed a tale telling and singing circle and three physical exercises sessions. Outside the group rooms I reviewed the materialistic conditions in the corridor and in the courtyard with a special attention to materials made for language acquisition. Besides, I also managed to take part in an extra-curricular activity, namely in an International Family Day. Here in this study, however, due to the limited space, only observations in the kindergarten activities will be discussed.

\section{Results}

\subsection{Grouping and Activities}

I visited 3 kindergarten groups. Although each group is a mixed-age group (i.e. no strict division among children according to their age), The Young Group involves very young children between 3 and 4 while The Middle Group and The Old Group have older children, between 4 and 6 . The days I managed to observe them, The Young and The Middle Groups each was made up of 19 children, and The Old Group up of 23 children. In The Young Group (Figure 1) 6 foreign children were present whose pseudonyms with the real name of their country are used all over the dissertation: Momchil (Bulgaria), Ingrid (Norway), Karin (Sweden), Jesper (Sweden), Vuokko (Sweden), and Chessa (USA). 


\section{The Young Group}

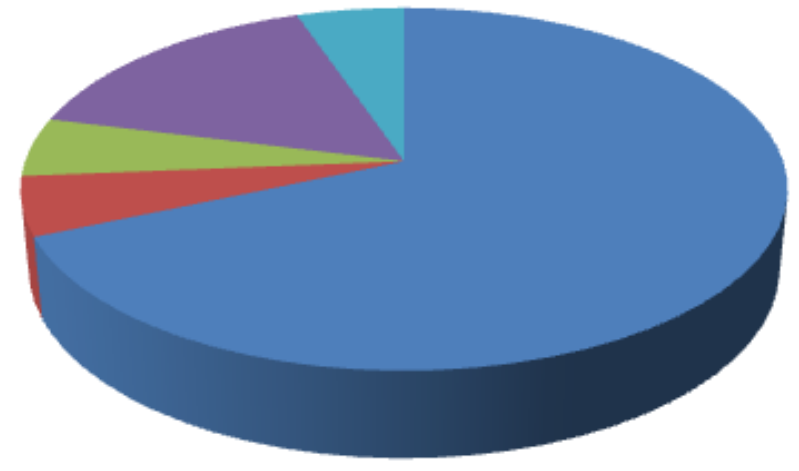

- Hungarian (13)

- Bulgarian (1)

Norwegian (1)

- Swedish (2)

American (1)

Figure 1: Division of The Young Group according to nationalities

In The Middle Group (Figure 2) from among the 19 observed children 6 came from foreign countries: Anastasiya (Bulgaria), Luboslaw (Poland), Adalstein (Norway), Emily (USA), Bailey (USA), and Neil (USA).

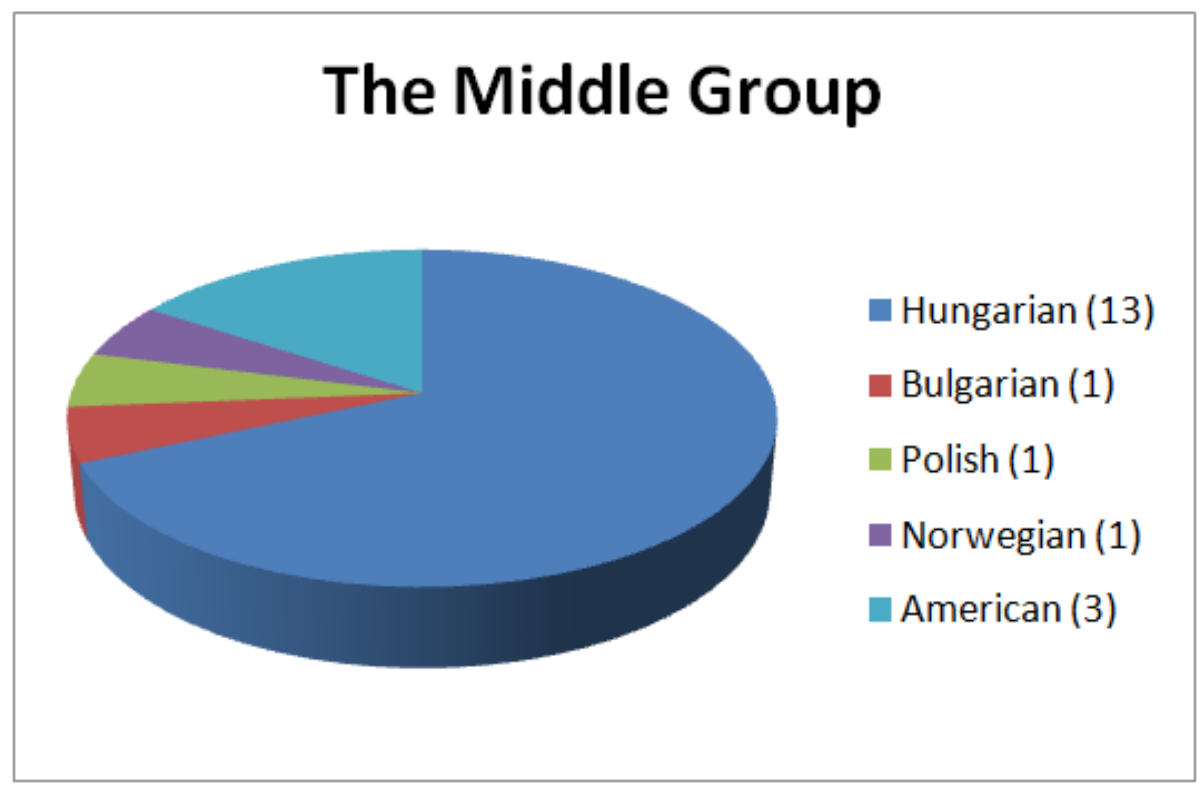

Figure 2: Division of The Middle Group according to nationalities

In The Old Group (Figure 3) there were 23 children present. 5 of them came from two different foreign countries: Halldora (Norway), Mjoll (Norway), Mandy (USA), Jonas (USA), and Bradley (USA). 


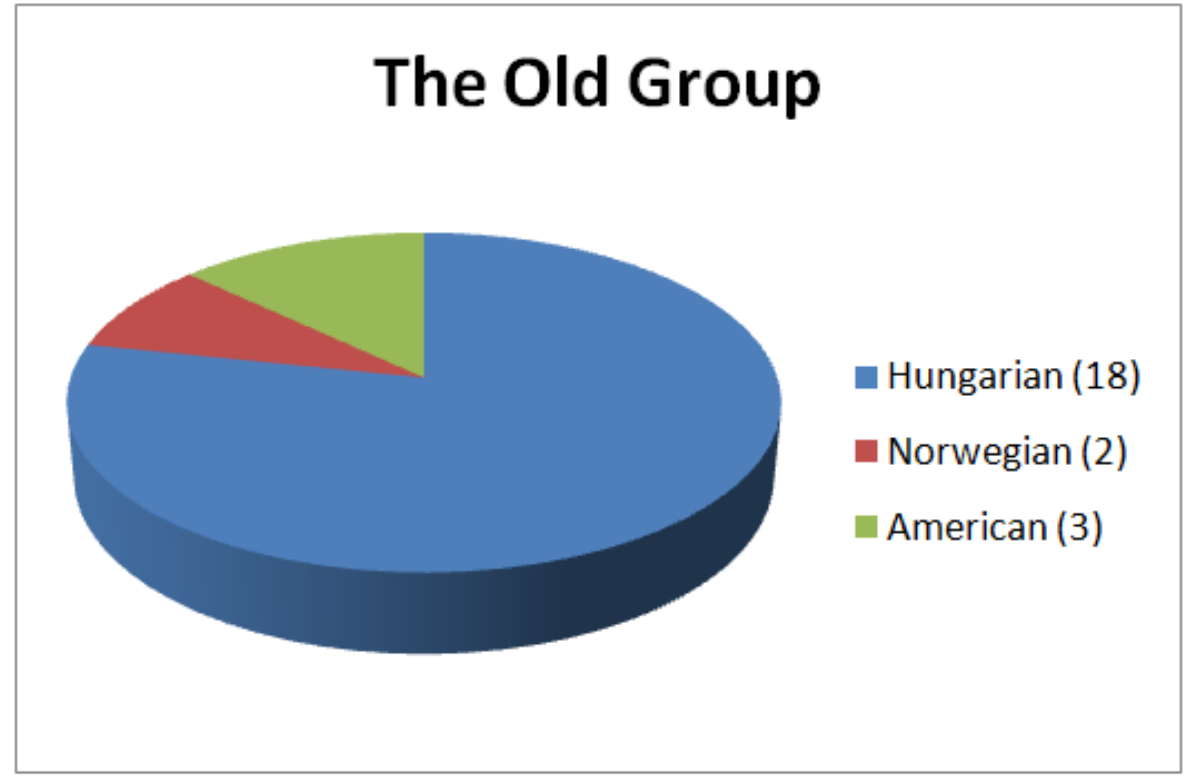

Figure 3: Division of The Old Group according to nationalities

Altogether I observed 3 kindergarten groups with 61 children form among which 17 came from five different foreign countries and 44 were Hungarians (Figure 4). In The Young and The Middle Groups there was a kindergarten teacher and a pedagogical assistant, while in The Old Group there were two kindergarten teachers and a pedagogical assistant present.

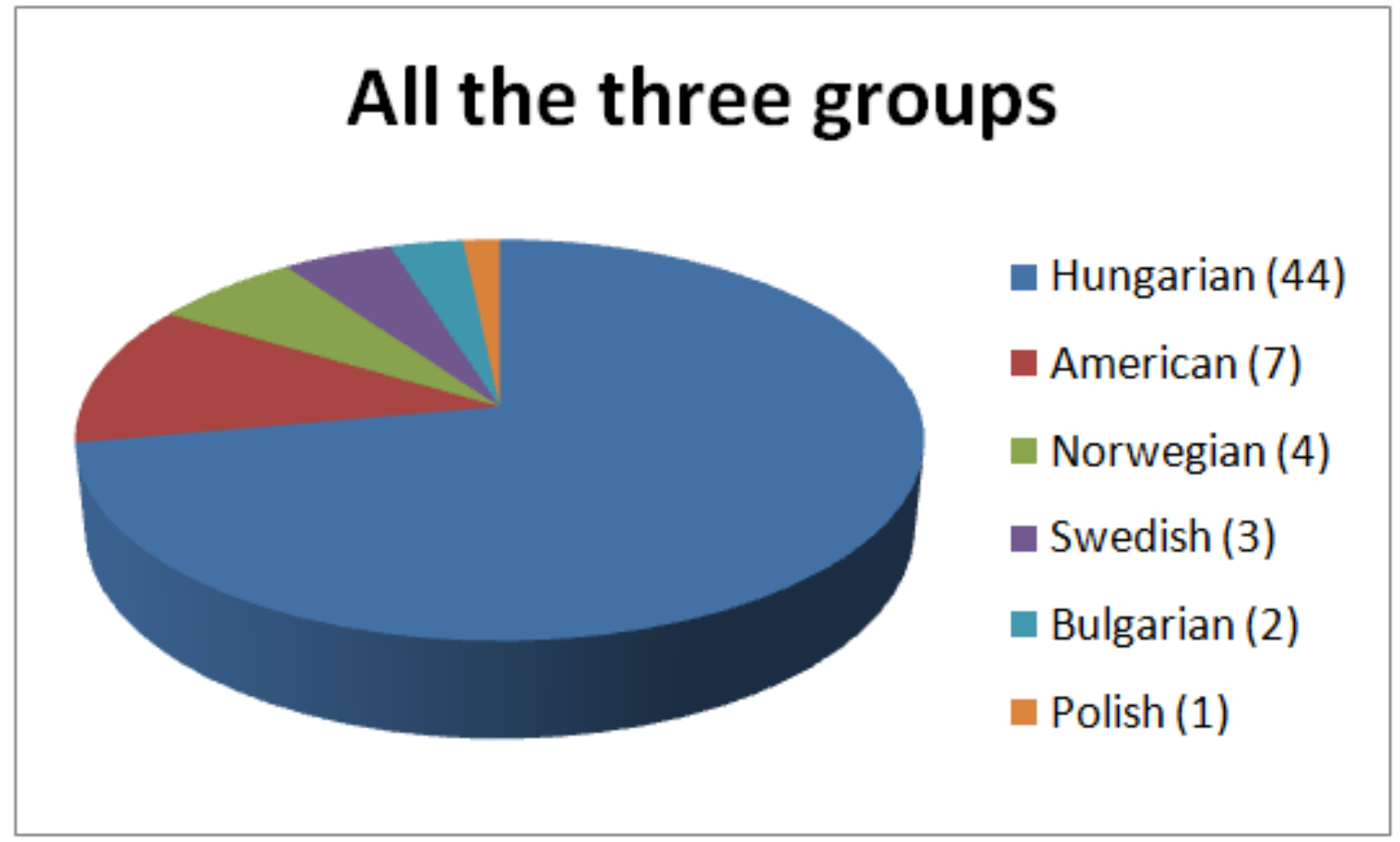

Figure 4: Division of all the three groups according to nationalities

In The Young Group children were preparing for Mother's Day, in The Middle Group there was no particular topic of the day as the school year was already over, and The Old Group was preparing for Easter. In The Young and Old Groups the cultural and linguistic aims were preparing for holidays with visual aids, songs and rhymes, 
while the concrete aim of the activities were missing in The Middle Group, due to the fact it has been discussed above. The pedagogical aim in all groups was a revision and maintenance of skills children have learnt in the previous school year, e.g. eating habits, manual skills and linguistic skills. Naturally, in two groups children were also preparing for holidays.

Procedures were similar in all groups. Days were running adjusted to the daily schedule, which involved an individual morning greeting (when a child arrived), free time activity, calling-over, washing hands, a 10 o'clock snack, cleaning up together, everyday physical exercises, initials or sessions, outside/ inside free-time activities, daily hygiene, lunch, preparing for sleep, sleeping, afternoon snack, free-time activity and departure.

In free play time activity children chose the games and toys according to their interest. Kindergarten teachers had prepared the space for the activities and worked as mediators. The most popular games in The Young Group were fishing with magnets, building with animals on the carpet, memory game, and a cutting game with scissors and plasticine. In The Middle Group children liked drawing with crayons and chalk at a table, building a town on the carpet, and playing with LEGO. Children in The Old Group made Easter eggs from flour plasticine at a table, built an airport on the carpet, and played a memory game. Playing went on in pairs, small groups or individually, with or without the kindergarten teachers or the assistants. (I will turn back to the question of grouping at the linguistic description of the different plays later in this chapter.) After cleaning up I observed three sessions which I recorded: in The Young Group a story telling session, and in the two other groups two P. E. sessions. After meals (snacks and lunch) free time activities were going on.

Parents' roles in the daily routine were reduced to the few minutes when they brought their children to the kindergarten and took them home in the afternoon. With the Hungarian parents kindergarten teachers spoke Hungarian, while the vehicle language between foreign parents and kindergarten teachers was English even with nonnative English parents, too. Few fathers bring their children to the kindergarten but a Bulgarian father appeared during my visit. Parents did not stay long and their communication usually contained some information just like the American mother's in The Old Group who told the kindergarten teacher in English to change her child's clothes if they go outside.

Linguistic features could be observed together with social grouping. In The Young Group Vuokko, whose mother is Finnish and father is Swedish called Jesper, the Swedish boy to play, probably, in Swedish ("Komm, Jesper!") and then they were playing together using the Swedish language continuously. I must admit here, however, that as I do not speak Swedish, I cannot state this definitely, yet I might deduce it from the background information according to which Vuokko is Swedish-Finnish bilingual and Jesper's L1 is Swedish. On the other hand, as I speak a little Finnish, I may say that it was not the Finnish language the children used between themselves.

The American Chessa and the Norwegian Ingrid were playing with plastic animals on the carpet. Chessa gave Ingrid instructions in English, like "Put the crocodile to the zoo!" or "Take another one!". Although Ingrid did not answer her in English, she followed the instructions. Children were very mobile and new groups were constantly forming. Karin, the Swedish girl joined the Vuokko-Jesper pair playing together using the Swedish language. Ingrid left Chessa and continued playing with a group of Hungarian children where her reactions showed that she understood Hungarian, but she did not use the language. In between I asked Vuokko "Mistä sinä olet kotoisin?" 
("Where are you from?") in Finnish. She was also talking about her family in Finnish expecting me to understand. When she realised that my Finnish was not enough to understand her, she was trying to explain some Finnish words to me at snack time by showing and miming ('voileipä' = "bread and butter"; "Hyvää ruokahalua!" = "Enjoy your meal!" etc.).

A few children were playing alone, for instance Ingrid, who was dressing up a wooden bear family. When I asked her in Hungarian ("Mit csinálsz?") she did not answer. Later I asked about the bear family still in Hungarian, and she started to answer me in the same language: "Ez a mama. Ez a papa. Ez Krisztina. Ez én vagyok." "This is mother. This is father. This is Christina. It's me.") When I inquired "Ez a te családod?" ("Is this your family?") she gave me a positive answer in Hungarian. When I repeated the same question in English, she gave me a positive answer again, but this time in English. When she put a bear aside, I asked her "Miért nem tetszik ez a mackó?" ("Why don't you like this bear?") "Mert..." ("Because..."), but she did not finish the sentence. She showed me the bear's mouth which curved down and told me a Norwegian word I could not understand. She repeated the word louder and louder while she became more and more impatient. When I told her "Sír. Szomorú." ("He's crying. He's sad."), she accepted my version and repeated in Hungarian: "Igen. Sír. Szomorú." ("Yes. "He's crying. He's sad."). After a while Chessa and Ingrid were together again playing memory game with animals. Chessa was speaking English all the time: "The zebra goes there. One goes there ... here. It's a bird right there." Ingrid took part in the game but did not speak either Hungarian or English. When the kindergarten teacher went up to them, she asked Ingrid in Hungarian "Segítesz Chessának?" ("Will you help Chessa?") - "Nem, nem tudom ezt." ("No. I cannot do it."), came the reply in Hungarian. While Chessa was speaking English during the memory game, Ingrid used basically Hungarian: "Ez itt egy fish." or "piros egg".

There were two more groupings worth mentioning: Momchil and Jesper were very often together. They were speaking their own mother tongue: Momchil the Bulgarian and Jesper the Swedish language even while playing e.g. cutting figures and using plasticine. Hungarian children were speaking exclusively Hungarian, even when they were playing with foreign children. Hungarian children did not go up to foreign groups by themselves. On the other hand, when a foreign child joined them, they let her/ him join but did not change the language. Also some Hungarian children prefer playing alone, e.g. Noémi who was not involved in any children's group during the day. At the same time she was very much interested in my presence, gave me a gift and was talking about herself gladly.

Linguistic features from the kindergarten teacher's side were more observable when she got control over the whole group. After the free play activities she called the children to tidy up the room. She did it with the help of a short English song (one line repeated several times) whose similar version was also told in Hungarian: "Listen children, clean up time...!" and "Dolgozni szaporán, felmossuk a konyhát..." ("Let's work quickly, we'll scrub the kitchen...") Afterwards, with a similarly simple line the teacher raised children's attention: "Listen, children, be quiet!"

\subsection{Observation in The Young Group}

Calling-over went on in a playful way in The Young Group, where children were sitting together with the kindergarten teacher and the assistant on the carpet. At this time the teacher checked children's presence with the same question in English: "András 
Baráth, what's your favourite animal?" "Dino." etc. Not whole sentences were expected; one word was enough. Most Hungarian children answered in Hungarian which was translated by the teacher into English: e.g. 'paci' ® 'horse', 'sárkány' ${ }^{\circledR}$ 'dragon', and the pronunciation was taken care of 'dino' [di:nó $₫$ 'dainou]. Some of the names were not corrected, however, e.g. 'delfin' ('dolphin') and 'krokodil' ('crocodile'). English was used as the main language in this session (e.g. "Raise your hand if you want to go home after lunch."), but sometimes Hungarian was used even in the communication with foreign children. The kindergarten teacher consistently talked to Vuokko in Hungarian: "Várj egy picit, Vuokko!" ("Wait a minute, Vuokko."). American English could be observed, e.g. "We're waiting for you in the restroom." Counting the number of the children present was going on in Hungarian. At the end of this procedure, two children were sent out to the nurses to report how many children would stay in the kindergarten after lunch. One child was Hungarian and the other is American. The instructions (what to say to the nurses) were given by the teacher slowly in Hungarian. Finally, lining up was also introduced with an English rhyme: "Listen, children, line up now!" After washing hands children were waiting in the corridor where the teacher initiated to sing the song learnt for Mother's Day together ("We love mothers...").

As an illustration, she asked each child in English to go up to her: "Momchil, come here. I'd like to hug you. I'd like to kiss you." In this part she spoke English to everybody, even to the Hungarian children. At the same time she asked the pedagogical assistant in Hungarian. Apart from the procedure, she spoke English to Karin ("Sit nicely. Put down your leg. Thank you.") and Hungarian to Vuokko ("Vuokko, gyere ide!" = "Vuokko, come here!") and she seated the little girl on her lap.

According to the rules of the Hungarian system children were having their snacks and lunch together at different tables. The kindergarten teacher started in Hungarian: "Jó étvágyat kívánok!" ("Enjoy your meal!") and children answered in the same language: "Köszönöm, viszont kívánok!” ("Thank you. Same to you!") Children were playing while eating, especially with bread. The Hungarian Nelli said to Vuokko: "My name is 'krokodil'.", then Vuokko answered with the same method showing her piece of bread: "My name is 'zsiráf'." The kindergarten teacher warned the American girl in English: "Eat your bread, Chessa!" During meal the kindergarten teacher, the pedagogical assistant and the nurse were all ready to help. When children needed something, Hungarian children told the teachers, and foreign children raised their hands.

The actual initial or session led by the kindergarten teacher started after hygiene activities. It began with physical exercises in the disguise of a train journey. The kindergarten teacher introduced the exercises in Hungarian using popular rhythmic Hungarian children's verses like Tengerecki Pál (Paul Tengerecki) by Károly Tamkó Sirató or Mozdony (Train) by Gyula Illyés. The first one is about a boy who likes strolling all over the countryside and the second is the personification of a train. Also an English rhyme was used to show parts of body together with moving ("Hop one, two..."). Some children were singing and almost everybody was doing the movements. Chessa did not feel like joining, so she was staying apart first watching the children, then playing with a doll. Later Momchil joined her. The kindergarten teacher praises the children in Hungarian "Karin, ügyes vagy!" ('Karin, you're clever!') Later she invites Momchil to the circle in Hungarian.

The P.E. session was followed by a rhyme which Hungarian boys say at Easter when they sprinkle girls with water or perfume. This rhyme was very carefully introduced with visual aids which helped children imagine the situation and make out the Hungarian words, e.g. 'fecske' ('swallow'), 'ház' ('house') and 'domb' ('hill'). The words and the rhyme were practised only in Hungarian. The teacher asked Vuokko and Ingrid to 
recognise the pictures and they answered in Hungarian saying 'piros tojás' ('red egg') or 'fiú' ('boy'). Then a ladybird was put together out of coloured paper forms. The name of the animal and its different parts were told in Hungarian: 'katicabogár' ('ladybird'), 'pötty' ('spots'), 'lábak' ('legs'). Also little ladybirds were handed to children and the instruction to pull them on fingers was given both in Hungarian and English stressing 'mutatóujj' ('pointer'). Then a Hungarian song about a ladybird (Katicabogár by Vilmos Gryllus) was sung together.

In the tale telling part of the session the kindergarten teacher tells a tale about the lost goose. Children sit around her on the carpet and listen to the tale. The teacher pretends that they are a part of a theatre play and asks in Hungarian: "What do we do if we like the performance?" Children answer: "We clap," and they do so. The tale goes in Hungarian. Some paper puppets on a wooden stick illustrate the tale. At the beginning of the tale the question "How many little geese were born?" is asked, then children count and answer in Hungarian. The tale is interrupted three times by short songs which intend to comfort the goose that seems to have lost her mum. Two songs are sung in Hungarian ("Száz liba egy sorba..." and "Látod, kisliba, meglett a mama...") and one in English ("Don't cry little goose, we will take you home..."). At the end of the 'performance' children clap and Chessa wants to take home the puppets. The kindergarten teacher tells her in English that she would need them again later, so she cannot give them to her.

\subsection{Observation in The Middle Group}

Older children go to The Middle Group than into The Young Group and their age can be noticed in their play and communication as they have known each other for a longer time. Therefore in The Middle Group children are more relaxed and there are a few "old friends" who usually play together. Luboslaw, a Polish boy speaks to the kindergarten teacher fluently in Hungarian. "Megetted a süteményt?" ("Have you eaten the cake?") asked a teacher and he answered "Majd holnap." ("Tomorrow.") He was not embarrassed at my presence either. He involved me immediately in castle building on the rug. He spoke to me Hungarian telling me that although he was playing with Hungarian boys, his real friend was absent. When I inquired in Hungarian who his friend was, he replied: "Mariusz, de ő polska." ("Mariusz, but he is polska."). "Szóval lengyel." ("So, he is Polish."), I stated. "Nem, polska!" ("No, but polska!") When the kindergarten teacher warned Luboslaw in Hungarian not to hit other children, he stopped doing so. When I asked him about the animals in the zoo on the rug, he clearly made a difference among them. E.g. "Ez oroszlán vagy tigris?" ("Is this a lion or a tiger?") "Oroszlán." ("A lion.") When an American boy, Blake joined the Polish-Hungarian group of boys, the vehicular language was Hungarian. Matyi, when he realised that I was speaking to the children, asked me: "Te tudsz magyarul beszélni az angolokkal?" ("Can you speak Hungarian to the English children?")

Anastasiya and Emily make another mixed (Bulgarian-American) pair. They were inseparable also during my visit. They are building an animal farm and speaking English. Emily: "They're horses. This is their house." Anastasiya: "They're ghosts. The horses are scared." When the Bulgarian girl was speaking to me, she used English. Matyi was ready to help me and showed me his translating skills: "Azt mondja, kísértet jön." ("She says a ghost is coming.") Free playing activity is ended up with cleaning up. The assistant says: "Listen, children, clean up time!", and then in Hungarian: "Dolgozni szaporán..." ("Let's work quickly...") 
The common activity led by the kindergarten teacher in this group was physical exercises. It was embedded in a game called "Fire, water and air". Different activities were connected to these words. It means that children were expected to do the following movements on hearing the calling words: fire - crouching, water - running, air - lying on the floor. One more activity was added to the word: on hearing 'sunshine' children had to lie down on the back. The teacher was playing with the words and also with the rhythm of the game (slow and quick movements were required). Children followed the instructions which were given only in Hungarian.

\subsection{Observation in The Old Group}

Just like in the previous two groups, social grouping of children influenced language use in The Old Group as well. Halldora and Mjoll came from the same country (Norway) and they usually play together. They used their mother tongue, the Norwegian language, during my visit, too. Klári, a Hungarian girl joined them while cutting Easter eggs and spoke English to the girls: "It's orange. It's pink." Klári wanted to show me her English command and started to sing and dance at a nursery rhyme: "Two little dicky birds sitting on a tree..." A group of Hungarian boys declared that they were soldiers and did not like Klári's singing, so they kept their ears stopped. In between, the American Mandy arrived who started to play alone till Hungarian children called her to play with them. She accepted the invitation, but the communication was not smooth: Hungarians spoke Hungarian to her, but she did not respond. Two more American boys arrived who started to play together immediately. First, Jonas and Bradley were playing a memory game and Jonas listed the names on the cards in English: "clown, plane, ghost, etc." When I ask him if he could name them in Hungarian, a negative answer comes. Meanwhile the boys were talking about animals: "We have four kittens. I saw the Dad cat, but his eyes were broken." When they got bored with the memory game, they moved onto the rug to play with airplanes. Jonas spoke more ("Help me, here. Oh, my God!"), Bradley moved and jumped with the planes but his words were not clear.

The teacher initiated activity in this group, just like in The Middle Group, was physical exercises. The kindergarten teacher used exclusively Hungarian in this section. She took part in the activities (walking, stretching, tiptoeing etc.) while she was saying what they were doing. Before they started the exercises, a Hungarian boy counted the boys in Hungarian and then Halldora, the Norwegian girl was asked to count the girls. She was offered to count either in Hungarian or in English. She chose Hungarian, and counted fluently. When the kindergarten teacher asked in Hungarian how many girls were present, she answered in the same language: "Nyolc." ("Eight.") In the second part of the P.E. session children were boxing in the air and for some safety reasons the teacher asked them to box only forward. Halldora did not seem to catch it and the others warned them in Hungarian: "Elöre, Halldora, elöre!" ("Forward, Halldora, forward!") The last part covered hurdle race with a ball where all the instructions were given only in Hungarian. Although the pedagogical assistant was present, this time she did not speak either language.

The language share between the teacher and the assistant could be observed easily as the kindergarten teacher used almost exclusively Hungarian and the assistant used English both with Hungarian and foreign children. Dorottya, the assistant uses English systematically and consistently: if she does not remember a word, she rather consults the dictionary than says it in Hungarian. This time she looked up vocabulary connected with flying: "power plant" and "runway". In this group the kindergarten 
teacher's English was limited to some panel expressions or instructions, e.g. "Silent, please!" "Come here." "Let's start." "Close your eyes." etc. Signals were repeated by her in English and Hungarian, too: "Clean up, clean up, everybody!" and just after it in Hungarian: "Dolgozni szaporán, felmossuk a konyhát..." ("Let's work quickly, we'll scrub the kitchen...") At meal time "Jó étvágyat!" ("Enjoy your meal!") and the reactions were heard also only in Hungarian, just like in the other groups.

\subsection{Discussion and Conclusions}

One might expect that in a multilingual kindergarten a foreign language, like English here, is a dominant language. Hungarian, however, can easily be the lingua franca among children. As Luboslaw's (Polish) chosen L2 is Hungarian and he is a leading person in the group, children follow him, even if they have different mother tongues. Blake's (American) L1 is English, yet he joins the Hungarian speaking group of children. Matyi's (Hungarian) remark shows two phenomena: on one hand, some children are still surprised to see a bilingual model, and on the other hand, in his mind the notion of language and nationality have not yet been separated.

In some cases children distinguish languages and produces code-switching. For instance, this phenomenon has been developed in Ingrid's, a Norwegian kindergartener's daily routine. During play time she did not hesitate to recognise the two (Hungarian and English) languages, moreover, she responded, even if in a laconic way. At the same time, her productive language skill is limited in foreign languages; it is the reason why she turns to her L1 when she wants to get into longer conversations. When the conversation dies (this time according to the receiver's insufficient language command) linguistic frustration, accompanied by social frustration, can be noticed. The example also reveals that the difficulty of the pedagogical task is multiplied if there is no common language between the child and the teacher. It is an obvious force of frustration.

Children's language choice sometimes tends to be influenced by the kindergarten teacher who can choose only from among Hungarian and English. In the cases of non-Hungarian/ English speaking children teachers need great empathy and patience. Vuokko, for instance, is definitely allowed to use Hungarian, which shows that children's language choice is respected and supported. Vuokko comes from a bilingual Swedish-Finnish family, and in the kindergarten she tends to prefer Hungarian instead of English, especially with the kindergarten teacher. It is the fact that the teacher knows and confirms. In the case of the American kindergartener, who was also given instructions in Hungarian, we may conclude that the teacher has realised that the girl understands Hungarian and wants to develop this language. It is supported by the way how she gives the instructions, i.e. very slowly and in an articulated way. Using different languages including languages which are not their mother tongue, children show personal and linguistic flexibility. It means that they are brave enough to be involved in conversations in $\mathrm{L} 2$, and they even enjoy playing with foreign words. It plays an important role in developing a linguistic self-confidence and serves as motivation for L2 use and acquisition.

Two other language phenomena are worth commenting: pronunciation and vocabulary. Kindergarten teachers are also aware of the "critical period theory", according to which early childhood is an absolutely ideal time to acquire the right pronunciation. Although, today, when English is used in very dispersed geographical areas as $L 1$, moreover it is the most global language that is used as $L 2$, there might be debates 
about the "right" pronunciation. Yet, teachers would like to pass on the pronunciation they follow and correct phonological errors as shown. As far as vocabulary is concerned, it is apparent that American vocabulary is used. It must be due to the daily contact with American parents, who are considered to be the authentic users of the English language by the kindergarten teachers, thus they serve as language models and their examples are followed. In this case, e.g. with the word 'restroom' which can hardly be heard in British English context.

The results of the observations suggest that already at a very young age, in institutional circumstances, language development requires detailed and elaborated preparation. In a Hungarian session words were taught to children with the help of demonstration (here: visual aids) while learning by doing (here: movements) could also be observed as a useful technique. Songs were not translated which shows the method of monolingual language education. With the help of the soothing music, children naturally felt the relaxing atmosphere, and on the basis of the vocabulary, which had been introduced beforehand, children could understand the song. Another interesting conclusion can be drawn at this point from the fact that Hungarian and foreign children were asked to do these activities together. It proves that mother tongue education can be extended and carried out as integrated education even from linguistic aspects. It means that L1 education and L2 education at a very early stage might not differ a lot. If it is done carefully, children might learn languages parallel. It is also an answer for sceptics, according to whom foreign language learning can start only when L1 learning is "finished".

We may also conclude that the kindergarten's Hungarian-English bilingual programme is accurately and consistently carried out in daytime activities. The technique, i.e. inviting children for an activity is usual, for instance, in Hungarian-German bilingual kindergartens as well. These kinds of imperatives are called "signals" which introduce different activities in the daily routine. The use of them suggests that kindergarten teachers find it a useful tool in a multicultural setting as well; first because it gives a frame and structure to children's day, which is highly needed at this age, and secondly, its bilingual manifestation becomes a basic element of bilingual education. For instance, "Make a circle big, big, big" can be sung before playing a circle game, or "This is the way we wash our teeth" before going to the bathroom together.

Apart from sessions, even dead time can be used up well with games and songs in language development. Teaching a song in English proves that with the appropriate methods monolingual teaching is a useful and beneficial way of second language education, already in early childhood. Completing it with Total Physical Response (TPR) it might be linguistically rewarding and emotionally satisfying for young children. At the same time, kindergarten teacher's use of English in a situation and use of Hungarian in another one shows that the teacher serves as a bilingual model (Talabér, 2004) for the children. This concept differs from the "one language - one person" method where each person represents one language.

It is easy to see that the poems were recited not only because of their content. What is more important than the actual meaning of the words is the chance for playing (moving around like a train), and the melody and rhythm of words that are formed into poems. Using rhymes and rhythms, also short poems is the usual way of L1 and L2 development in the kindergarten. It has been revealed that languages, especially foreign languages can be best acquired if words are accompanied with music and/ or rhythm and movements. Besides, they serve as excellent motivation for playing and building communities. In this case the English rhyme implies numbers 
as well and actions which can be imitated, while words and their meanings are easily memorised in a simple but effective way. Moreover, poems and rhymes can also be considered cultural elements of education. The kindergarten teacher's short praises with the appropriate meta-communication (mimics and gestures), even for those who do not understand every Hungarian word, suggest a positive and motivating attitude and creates a relaxing, playful atmosphere which should be the basis of all kinds of education, also of language education.

According to modern children's literature methodology, tales in L1 should be told with no tools and dramatisation in the kindergarten, because children should use their imagination instead of receiving a ready-made version. In our observation, however, the tale was presented not only to Hungarian children, but also to an international "audience". Therefore, elements of ESL methodology can be traced: e.g. the tale was accompanied by illustrative puppets and language was not only heard but explained. The inserted songs bear rhyme and rhythm of the language and onomatopoeic words are used, e.g. the sound of a goose ("gá-gá-gá" in Hungarian). The English song also mirrored the bilingual characteristics of the kindergarten programme. Although it would not have been necessary to give the English version, it was not disturbing, as it was clear how it was connected to the tale: it had the same tune as the previous Hungarian song.

As we have already pointed out, integrated language development can naturally be carried out in the best way in P.E. sessions. Learning by doing is an appropriate method which can be beneficial already in early childhood. During our observation, non-native Hungarian/ English children were represented by a Norwegian girl, whose L1 was spoken neither by the kindergarten teachers nor the majority of the children. It can clearly be seen that the two working languages were offered to the child, and she chose one of them (Hungarian), which means that she feels already comfortable with the language, or at least some of its basic elements (e.g. numbers). Moreover, she understood instructions while they were shown to her. It can be concluded that language development should and can be done only carefully and gradually. Referring again to the TPR (Total Physical Response) we must declare that instructions can be followed much easily when they are shown at the same time. According to the kindergarten's philosophy one of the working languages is used without translation and integrated education was going on, i.e. Hungarian and foreign children were not separated during the sessions.

Besides the different activities, is also worth examining the language share between the kindergarten teachers and the assistant. As only one of the teachers speaks fluent English in every group and the assistant is actually the one who helps with English, it is quite usual that two methods mix. One of them is the "one person -one language" method, where one language can be connected to one person, and the other is the "bilingual model", when the kindergarten teacher speaks both Hungarian and English. Children feel relaxed and secure in the presence of the person with whom they can share the same L1. This is, however, not available for everybody, just for Hungarian and English speaking kindergarteners.

Observations suggest that children, apart from the language use among themselves, often change their playfellows, the result of which is creating new communities. The communities are not language determined, i.e. their formation might be rather due to the type of game and children's momentary interest than the actual language use. This conclusion seems to be supported by the fact that even if children themselves do not speak a language, they may accept their group-mates and join them. Besides language diversity, cultural diversity is also apparent in the kindergarten. In this group 
kindergarten teacher was asking children about national flags while they were talking about a previous event in the kindergarten. A Hungarian child could answer the question asked by the kindergarten teacher in Hungarian: "What was the Polish flag like?" ("Red and white."), and another child added that he preferred the Star-Spangled Banner. "Whose flag was that?" asked the teacher. As children did not answer, she was adding a leading remark: "You know, it's Emily's and Neil's flag". "Then, it's American" answered Matyi in Hungarian. It shows that overt cultural questions can be asked even at this stage of education in a multicultural kindergarten. Naturally, cultural issues should be discussed at the appropriate level and according to age characteristics. The result will be better if abstract notions are transferred into tangible questions and based on children's previous experience, in this case for instance on the sight of the flags that could be seen in a kindergarten event.

Kindergarten is the ideal place for holistic education where besides verbalism, all senses are drawn in, according to the modern so-called "global education" (Kivistö, 2008). Just like language education theories make a difference between language acquisition and language learning, generally, within education we should make a further distinct between 'teaching' and 'development'.

\subsection{Summary}

During observation we were trying to gain insight into how grouping was formed and what kind of activities children took part in. Discussion centred on the language use and language choice of the children and conclusions were drawn about the integrated language and cultural development of the children. Besides, we also tried to show how observation as a research method can be applied under multicultural circumstances. Even if it is not the easiest way of gaining information among the very young, its benefits can be noticed in the results. This example will hopefully encourage researchers to go on developing the method and add it to their research repertoire.

\section{References}

Bartha Csilla (1999): A kétnyelvüség alapkérdései. Nemzeti Tankönyvkiadó, Budapest.

Byram, M. (1997): Teaching and Assessing Intercultural Communicative Competence. Multilingual Matters, Clevedon.

Byram, M. \& Zarate, G. (1994): Definitions, Objectives and Assessment of Sociocultural Competence. Council of Europe, Strasbourg.

Cs. Czachesz Erzsébet (1998): Multikulturális nevelés. Mozaik Oktatási Stúdió: Szeged.

Eisenhart, M. (2006): Representing Qualitative Data. In: Green, J. L., Camilli, G. \& Elmore, B. P. (eds.), Handbook of Complementary Methods in Education Research. Lawrence Erlbaum Associates, Inc., Hillsdale, 567-583.

Kivistö, J. (2008): How does global education stay alive and vital in every day school activities? Presentation made at the workshop of Opeko, Finland on Supporting Teaching in a Multicultural School in 2008, Tampere, Finland.

Kovács Judit (2002): Az alsó fokú angolnyelv-oktatás helyzete Magyarországon az európai Unióhoz való csatlakozás küszöbén. Modern Nyelvoktatás, 8. 4. sz., 30-36.

Kovács Judit (2008): Innováció a kéttannyelvűségben: a párban történő magyar-angol általános iskolai program vizsgálata. In: Vámos Ágnes és Kovács Judit (szerk.), A két tanítási nyelvü oktatás elmélete és gyakorlata 2008-ban: Jubileumi tanulmánykötet. Eötvös József Könyvkiadó, Budapest, 187-212.

Kovács Judit (2009a): A gyermek és az idegen nyelv. Eötvös József Könyvkiadó, Budapest. 
Kovács Judit (2009b): Az óvodáskori nyelvtanulás, mint jelenség.

URL: http://www.pagony.hu/az-ovodaskori-nyelvtanulas-mint-jelenseg, Retrieved April 25, 2013

Labov, W. (1972): Sociolinguistic Patterns. University of Pennsylvania: Philadelphia.

Navracsics Judit (2007): A kétnyelvü mentális lexikon. Balassi Kiadó, Budapest.

Navracsics Judit (2008): A kétnyelvüség pszicholingvisztikájáról - dióhéjban. In: Vámos Ágnes és Kovács Judit (szerk.), A két tanítási nyelvü oktatás elmélete és gyakorlata 2008-ban: Jubileumi tanulmánykötet. Eötvös József Könyvkiadó, Budapest, 43-60.

Navracsics Judit (2010): Egyéni kétnyelvűség. Szegedi Egyetem Kiadó, Szeged.

Roberts, C., Byram, M., Barro, A. Jordan, S. \& Street, B. (2001): Language Learners as Ethnographers. Multilingual Matters, Clevedon.

Strategic Airlift Capability (2013): NSPA - NATO Support Agency. URL: from http://www.nspa.nato.int/en/organization/NAMP/sac.htm, Retrieved February 5, 2013

Talabér, F. (2004): Sprachziehung - Förderung der Sprechfreudigkeit in den Nationalitätenkindergärten. Nyelvi nevelés - nyelvi fejlesztés a nemzetiségi óvodákban. Croatica Kht, Budapest.

Torgyik Judit (2005): Fejezetek a multikulturális nevelésből. Eötvös József Könyvkiadó, Budapest.

Varga Aranka (2006): Multikulturalizmus - inkluzív oktatási rendszer.

URL: http://www.tki.pte.hu/admin/documents/varga/interkulturalis_neveles.doc, Retrieved February 5, 2013

Wragg, E. C. (1999): Introduction to Classroom Observation. (2nd edn.). Routledge, London and New York. 